\title{
$17 \beta$-Estradiol and Estrone Concentrations in Plasma and Milk During Bovine Pregnancy
}

\author{
D. A. Pape-Zambito, A. L. Magliaro, and R. S. Kensinger ${ }^{1}$ \\ Department of Dairy and Animal Science, Pennsylvania State University, University Park 16802
}

\begin{abstract}
Estrone $\left(\mathrm{E}_{1}\right)$ and $17 \beta$-estradiol $\left(\mathrm{E}_{2}\right)$ are present in milk, but the mechanism(s) that regulate their appearance in milk are not known. The objectives of this study were to determine the impact of stage of pregnancy on the concentrations of $\mathrm{E}_{1}$ and $\mathrm{E}_{2}$ in plasma and milk and to determine the correlations between plasma and milk $\mathrm{E}_{1}$ and $\mathrm{E}_{2}$ and with milk components throughout pregnancy. Blood and milk samples were collected from 13 cows every $28 \mathrm{~d}$ throughout pregnancy. The $\mathrm{E}_{1}$ and $\mathrm{E}_{2}$ were quantified in plasma and milk using RIA after organic solvent extractions and Sephadex LH-20 column chromatography. Plasma $\mathrm{E}_{1}$ concentrations averaged $0.8,16.9$, and $41.8 \mathrm{pg} / \mathrm{mL}$ in trimesters 1,2 , and 3 , respectively. The respective $\mathrm{E}_{1}$ concentrations in milk averaged $0.6,7.9$, and $27.1 \mathrm{pg} / \mathrm{mL}$. The $\mathrm{E}_{2}$ concentrations in plasma averaged $0.5,0.9$, and $2.0 \mathrm{pg} / \mathrm{mL}$; milk $\mathrm{E}_{2}$ averaged $0.3,0.9$, and $5.0 \mathrm{pg} / \mathrm{mL}$. Plasma and milk $\mathrm{E}_{2}$ concentrations were greater in trimester 3 compared with trimesters 1 and 2 . The $\mathrm{E}_{1}$ concentrations in milk were significantly correlated with plasma $\mathrm{E}_{1}$ concentrations $(r=0.77)$, percentage of milk fat $(r=0.50)$, and milk yield $(\mathrm{r}=-0.43)$. The $\mathrm{E}_{2}$ concentrations in milk were significantly correlated with plasma $\mathrm{E}_{2}$ concentrations $(\mathrm{r}=0.93)$, percentage of milk protein $(\mathrm{r}=0.63)$, and milk yield $(\mathrm{r}=-0.57)$. The milk-to-plasma ratio of $\mathrm{E}_{2}$ increased from 0.4 during trimester 1 to 2.2 in trimester 3 , which suggested that the mechanism(s) regulating the appearance of $\mathrm{E}_{2}$ in milk may change over the course of pregnancy.
\end{abstract}

Key words: estrone, $17 \beta$-estradiol, plasma, whole milk

\section{INTRODUCTION}

Recent epidemiological and case-controlled studies have associated dairy product consumption and the estrogens therein with a number of adverse health consequences. Milk-derived estrogens have been suggested

Received June 25, 2007.

Accepted September 21, 2007.

${ }^{1}$ Corresponding author: ron.kensinger@okstate.edu to contribute to male reproductive disorders (Sharpe and Skakkebaek, 1993; Ganmaa et al., 2001); increased risks for breast, uterine, and ovarian cancers (Cho et al., 2003; Li et al., 2003; Ganmaa and Sato, 2005); and adolescent weight gain (Berkey et al., 2005). Although some suggest that the concentrations of estrogens in milk are low in relation to human production rates (Erb et al., 1977; Hartmann et al., 1998; Pape-Zambito et al., 2007), others argue that milk contains considerable quantities of estrogens (Remesar et al., 1999; Ganmaa et al., 2004; Qin et al., 2004). Ganmaa and Sato (2005) have hypothesized that milk produced by modern pregnant dairy cows in which a greater proportion of cows are pregnant compared with cows 100 yr ago contains large amounts of female sex hormones that promote the development of breast, ovarian, and uterine cancers. Therefore, it is important to reevaluate estrogen concentrations, particularly the more biologically active free estrogens in milk from pregnant dairy cows to assess human health risks.

Estrone $\left(\mathbf{E}_{1}\right)$ and $17 \beta$-estradiol $\left(\mathbf{E}_{2}\right)$ have been quantified in the milk of pregnant cows (Monk et al., 1975; Malekinejad et al., 2006). Monk et al. (1975) reported mean milk $\mathrm{E}_{1}$ concentrations of 57,35 , and $97 \mathrm{pg} / \mathrm{mL}$ and $\mathrm{E}_{2}$ concentrations of 85,52 , and $49 \mathrm{pg} / \mathrm{mL}$ in trimesters 1, 2, and 3, respectively. Malekinejad et al. (2006) recently used liquid chromatography tandem mass spectrometry to detect $\mathrm{E}_{1}$ and $\mathrm{E}_{2}$ in milk from 5 pregnant cows. The $\mathrm{E}_{1}$ concentrations averaged 9,57 , and $118 \mathrm{pg} / \mathrm{mL}$, and the $\mathrm{E}_{2}$ concentrations averaged 10,20 , and $21 \mathrm{pg} / \mathrm{mL}$ in trimesters 1,2 , and 3, respectively. Both Monk et al. (1975) and Malekinejad et al. (2006) sampled cows from trimesters 1,2 , and 3 of pregnancy; however, different cows were included from each trimester. Because the same cows were not sampled throughout pregnancy, one cannot distinguish animal variation from pregnancy-specific effects. Our lab reported greater quantities of $\mathrm{E}_{2}$ in milk from cows 141 to $210 \mathrm{~d}$ pregnant compared with cows $<141 \mathrm{~d}$ pregnant or nonpregnant cows (Pape-Zambito et al., 2007).

Batra et al. (1980) and Abeyawardene et al. (1984) reported that milk $\mathrm{E}_{2}$ concentrations were positively correlated with plasma $\mathrm{E}_{2}$ and suggested that plasma 
$\mathrm{E}_{2}$ concentrations were a predictor of milk $\mathrm{E}_{2}$ concentrations. Other reports have clearly shown an increase in plasma estrogens as pregnancy advances. Hoffmann et al. (1997) reported that plasma estrogen concentrations began to increase around $120 \mathrm{~d}$ of pregnancy in the cow; estrogen concentrations continued to increase as gestation progressed. Patel et al. (1999) used organic solvent extraction, liquid chromatography, and RIA to quantify free (as opposed to conjugated) plasma $E_{1}$ and $\mathrm{E}_{2}$ concentrations during pregnancy and found significant increases in $\mathrm{E}_{1}$ and $\mathrm{E}_{2}$ concentrations in plasma during each trimester. The concentrations of estrogens in milk were not determined in these studies.

Although estrogen concentrations in bovine plasma and milk during pregnancy have been quantified separately by individual researchers, the relationship between plasma and milk $\mathrm{E}_{1}$ and $\mathrm{E}_{2}$ concentrations throughout pregnancy has not been critically evaluated in the dairy cow. The objectives of this study were to collect plasma and milk samples from the same cows every $28 \mathrm{~d}$ throughout pregnancy to quantify $\mathrm{E}_{1}$ and $\mathrm{E}_{2}$. Also, because some have argued that milk from pregnant cows has unsafe amounts of estrogens, we wanted to determine if stage of pregnancy (trimester) significantly affected $\mathrm{E}_{1}$ and $\mathrm{E}_{2}$ concentrations in milk. Our final objective was to determine correlations between estrogen measurements and milk components to try to gain insight into the mechanism(s) that allow estrogens to accumulate in milk.

\section{MATERIALS AND METHODS}

\section{Animal and Sample Collection}

Fourteen pregnant Holstein cows ( $\mathrm{n}=7$ parity 1; $\mathrm{n}=6$ parity $2 ; \mathrm{n}=1$ parity 3 ) were selected from the Pennsylvania State University dairy herd for inclusion in the study. Herd health records were used to eliminate cows with previous reproductive and health problems including history of abortion, cystic follicles, difficulty conceiving ( $>5$ services per conception), displaced abomasum, and chronic mastitis. Herd reproduction was conventionally managed with a $60-\mathrm{d}$ voluntary waiting period before breeding was attempted. Cows entered the study after they were initially confirmed pregnant by ultrasonograpy followed by subsequent rectal palpation at an average of $52 \mathrm{~d}$ of pregnancy.

Blood and milk samples were collected an average of $11 \mathrm{~d}$ after confirmation of pregnancy by rectal palpation and thereafter collected every $28 \mathrm{~d}$ up to $250 \mathrm{~d}$ of pregnancy. All sampling procedures were approved by the Pennsylvania State University Institutional Animal Care and Use Committee (authorization no. 16216). On the designated sampling days, blood $(10 \mathrm{~mL})$ was aseptically collected from the coccygeal vessels into hep- arinized syringes from 0930 to $1100 \mathrm{~h}$. Samples were placed on ice immediately and transported to the laboratory. Hematocrit and plasma proteins were analyzed to assess health of animals. Hematocrit was determined using capillary tubes and centrifugation. Plasma protein concentrations were determined using a refractometer after the blood had been centrifuged for $30 \mathrm{~min}$ at $1,660 \times \mathrm{g}$ at $4^{\circ} \mathrm{C}$. The remaining plasma was frozen at $-20^{\circ} \mathrm{C}$ until analyzed for $\mathrm{E}_{1}$ and $\mathrm{E}_{2}$.

Milk samples $(100 \mathrm{~mL})$ were collected on the designated sampling days during the p.m. milking $(1700 \mathrm{~h})$. Duplicate samples were sent to the DHIA laboratory for fat, protein, lactose, and SCC analyses. The remaining milk was preserved with $0.02 \%$ sodium azide and homogenized for $15 \mathrm{~s}$ using a Polytron homogenizer (Brinkmann Instruments Inc., Westbury, NY) with a PTA probe on setting 5.5. These homogenized samples were stored at $-20^{\circ} \mathrm{C}$ until analyzed for $\mathrm{E}_{1}$ and $\mathrm{E}_{2}$. Body and milk weights for each cow on each sampling day were obtained from herd records.

Blood and milk samples from the cows were designated as collected during trimesters 1 ( 50 to $93 \mathrm{~d}$ pregnant, $\mathrm{n}=22$ ), 2 (94 to $186 \mathrm{~d}$ pregnant, $\mathrm{n}=47$ ), or 3 ( 187 to $246 \mathrm{~d}$ pregnant, $\mathrm{n}=29$ ). Cows on the study were intentionally allowed only a 30 -d dry period to continue blood and milk sampling to $250 \mathrm{~d}$ of pregnancy. One cow aborted its calf during the study; therefore, values for only 13 cows were used for data analyses.

\section{$E_{1}$ and $E_{2}$ Extraction from Whole Milk and Plasma}

The procedure for extraction of estrogens from milk was adapted from Monk et al. (1975) and Wolford and Argoudelis (1979) and is similar to that reported by Pape-Zambito et al. (2007). Homogenized milk samples were thawed in a warm water bath $\left(37^{\circ} \mathrm{C}\right)$ and vortexed for $10 \mathrm{~s}$ before aliquotting $3.0 \mathrm{~mL}$ into each of four 50 $\mathrm{mL}$ screw-cap glass extraction tubes. Milk in each tube was extracted with $9.0 \mathrm{~mL}$ of ethyl acetate:hexanes (1:1, $\mathrm{vol} / \mathrm{vol}$; ethyl acetate - HPLC grade, catalog no. JT928033, J. T. Baker, Phillipsburg, NJ; hexanes - Am. Chem. Soc. grade, catalog no. 293253, Sigma, St. Louis, MO). The mixture was vortexed for $30 \mathrm{~s}$ then placed on an orbital shaker for $15 \mathrm{~min}$. The vortex and shaking steps were repeated before incubation at $-20^{\circ} \mathrm{C}$ for $2 \mathrm{~h}$. The liquid organic layer from each individual sample was transferred to a glass tube and dried under $\mathrm{N}_{2}$ at $55^{\circ} \mathrm{C}$. The ethyl acetate:hexanes extraction was then repeated on the remaining aqueous phase. After freezing, the organic layer from the second ethyl acetate:hexanes extraction was transferred to the corresponding sample tube and dried. To remove triglycerides from the extract, $70 \%$ methanol (HPLC grade - catalog no. BJAH230-4, Burdick and Jackson, Muskegon, MI) was 
warmed to $55^{\circ} \mathrm{C}$, and $1.5 \mathrm{~mL}$ was added to the extract. This mixture was incubated at $55^{\circ} \mathrm{C}$ for $1 \mathrm{~h}$ with thorough mixing at $0,15,30$, and $45 \mathrm{~min}$. The mixture was subsequently incubated at $-20^{\circ} \mathrm{C}$ for $2 \mathrm{~h}$ then centrifuged for $30 \mathrm{~min}$ at $1,370 \times \mathrm{g}$ and $2^{\circ} \mathrm{C}$ to precipitate triglycerides. The supernatant solutions from the 4 replicates were pooled in a clean glass test tube and represented $12 \mathrm{~mL}$ of the original milk sample. This supernatant solution, which contained the steroid hormone fraction, was dried under $\mathrm{N}_{2}$ at 80 to $100^{\circ} \mathrm{C}$.

The estrogen-containing extract was reconstituted in $100 \mu \mathrm{L}$ of benzene:methanol (9:1, vol/vol; benzene - Am . Chem. Soc. grade, catalog no. 319953, Sigma) for transfer onto the chromatographic column used to separate cholesterol, $\mathrm{E}_{1}, \mathrm{E}_{2}$, and other residual steroids (Mikhail et al., 1970). Sephadex LH-20 (catalog no. 17-0090-10, GE Healthcare, Piscataway, NJ) was swelled with benzene:methanol $(9: 1, \mathrm{vol} / \mathrm{vol})$ and packed to $2.5 \mathrm{~cm}$ in glass columns (1-cm diameter - catalog no. 737-1006, BioRad, Hercules, CA). Steroids were eluted with benzene:methanol $(9: 1, \mathrm{vol} / \mathrm{vol})$ as described by Kensinger et al. (1986) and Pape-Zambito et al. (2007). The $\mathrm{E}_{1}$ and $\mathrm{E}_{2}$ elution patterns were verified with $2,4,6,7-{ }^{3} \mathrm{H}-\mathrm{E}_{1}$ (catalog no. TRK321, GE Healthcare) and 2, 4, 6, 7- ${ }^{3} \mathrm{H}-$ $\mathrm{E}_{2}$ (catalog no. TRK322, GE Healthcare). Other experiments in our lab confirmed the absence of cholesterol in the $\mathrm{E}_{1}$ and $\mathrm{E}_{2}$ fractions using this methodology. The $\mathrm{E}_{1}$ and $\mathrm{E}_{2}$ fractions were dried under $\mathrm{N}_{2}$ at $55^{\circ} \mathrm{C}$.

Plasma samples $(3 \mathrm{~mL})$ were processed similarly to the milk samples, except the triglyceride precipitation step was eliminated and 1 replicate rather than 4 replicates was extracted. In addition, a dry ice-ethanol bath was used to freeze the aqueous plasma layer before decanting the organic layer into a clean glass tube.

\section{$E_{1}$ and $E_{2}$ Quantification by RIA}

Dried $\mathrm{E}_{1}$ and $\mathrm{E}_{2}$ fractions from each plasma and milk sample were reconstituted in $125 \mu \mathrm{L}$ of wether plasma before quantification using an RIA specific for $\mathrm{E}_{1}$ (cata$\log$ no. DSL-8700, Diagnostic Systems Laboratory, Webster, TX) or $\mathrm{E}_{2}$ (catalog no. 07-138106, MP Biomedicals, Irvine, CA). Each sample was run in duplicate in accordance with manufacturer instructions. Preliminary studies evaluated parallelism, recovery of a standard mass of $\mathrm{E}_{1}$ and $\mathrm{E}_{2}$ added to samples, as well as recoveries of ${ }^{3} \mathrm{H}-\mathrm{E}_{1}$ and ${ }^{3} \mathrm{H}-\mathrm{E}_{2}$ added to milk samples (Pape-Zambito et al., 2007).

Tritiated $\mathrm{E}_{1}$ or $\mathrm{E}_{2}$ were run as internal standards with each set of samples extracted to estimate $\mathrm{E}_{1}$ and $\mathrm{E}_{2}$ recovery from plasma and whole milk. Tritiated $\mathrm{E}_{1}$ or $\mathrm{E}_{2}$ was added to pooled homogenized whole milk and plasma samples. After the final reconstitution step in wether plasma, the internal standards $(125 \mu \mathrm{L})$ were pipetted into $7.0-\mathrm{mL}$ scintillation vials with $5.0 \mathrm{~mL}$ of Ecolite scintillation fluid (ICN, Costa Mesa, CA) and counted on a Beckman LS 6500 scintillation counter (Beckman Coulter, Fullerton, CA). Control pooled milk and plasma samples were also run in the RIA with each set of unknown samples to determine intra- and interassay variation. Intra- and interassay $\mathrm{CV}$ averaged 2.0 and $9.5 \%$ for $\mathrm{E}_{1}$ and 8.5 and $9.6 \%$ for $\mathrm{E}_{2}$, respectively.

Reported $\mathrm{E}_{1}$ and $\mathrm{E}_{2}$ concentrations were corrected for recoveries of $\mathrm{E}_{1}$ and $\mathrm{E}_{2}$, respectively, as well as the volume of plasma or milk represented in the assay. Some plasma and milk samples had $\mathrm{E}_{2}$ concentrations that were below the limit of quantification (LOQ) of the assay. Any plasma or milk sample that predicted below the LOQ was assigned the LOQ value of $0.53 \mathrm{pg}$ of $\mathrm{E}_{2} / \mathrm{mL}$ of plasma or $0.14 \mathrm{pg}$ of $\mathrm{E}_{2} / \mathrm{mL}$ of milk. The limits of detection for $\mathrm{E}_{2}$ (provided by MP Biomedicals; adjusted appropriately for sample recoveries and volumes) were $0.40 \mathrm{pg} / \mathrm{mL}$ for plasma and $0.10 \mathrm{pg} / \mathrm{mL}$ for milk. All plasma and milk samples were within the LOQ for $\mathrm{E}_{1}(0.64 \mathrm{pg} / \mathrm{mL}$ for plasma and $0.16 \mathrm{pg} / \mathrm{mL}$ for milk). The limits of detection for $\mathrm{E}_{1}$ (provided by Diagnostic Systems Laboratory; adjusted appropriately for sample recoveries and volumes) were $0.05 \mathrm{pg} / \mathrm{mL}$ for plasma and $0.01 \mathrm{pg} / \mathrm{mL}$ for milk. Milk $\mathrm{E}_{1}$ and $\mathrm{E}_{2}$ mass was calculated by multiplying $\mathrm{E}_{1}$ or $\mathrm{E}_{2}$ concentration by the volume of milk produced at that milking. Milk volume $(\mathrm{mL})$ was calculated using the following conversion factors beginning with kilograms of milk: 1 $\mathrm{L}$ of milk/1.032 kg of milk, $1,000 \mathrm{~mL}$ of milk/ $1 \mathrm{~L}$ of milk.

\section{Statistical Analyses}

For statistical analysis, SAS version 9.0 (SAS Institute, Cary, NC) was used. To determine if concentrations of $\mathrm{E}_{1}$ and $\mathrm{E}_{2}$ in plasma and milk changed throughout pregnancy, PROC MIXED was used. Cow (random), parity (fixed), and trimester (fixed) were class variables with the following model statements: dependent variable (plasma $\mathrm{E}_{1}$, plasma $\mathrm{E}_{2}$, milk $\mathrm{E}_{1}$, milk $\mathrm{E}_{2}, \mathrm{E}_{1}$ mass, $\mathrm{E}_{2}$ mass, $\mathrm{E}_{1}$ milk:plasma, $\mathrm{E}_{2}$ milk:plasma, hematocrit, plasma protein, percentage of milk fat, percentage of milk protein, percentage of milk lactose, log SCC, milk yield $)=$ parity trimester. The repeated statement included trimester with subject $=$ cow. The compound symmetry covariance structure produced the best-fit statistics for all analyses. The LSM option was used to determine differences between trimesters. To determine the correlations among variables of interest, PROC CORR was used.

\section{RESULTS}

Blood and milk samples were collected every $28 \mathrm{~d}$ from 13 confirmed pregnant cows ranging from 50 to 
Table 1. Health indices, milk composition, yield, and mass of estrone $\left(\mathrm{E}_{1}\right)$ and $17 \beta$-estradiol $\left(\mathrm{E}_{2}\right)$ accumulated in milk during pregnancy

\begin{tabular}{lrrrr}
\hline & \multicolumn{3}{c}{ Trimester $^{1}$} \\
\cline { 2 - 4 } Analyte & \multicolumn{1}{c}{1} & \multicolumn{1}{c}{2} & \multicolumn{1}{c}{3} & SEM \\
\hline BW, kg & $635.0^{\mathrm{c}}$ & $688.6^{\mathrm{b}}$ & $741.6^{\mathrm{a}}$ & 18.9 \\
Hematocrit, \% & $26.9^{\mathrm{b}}$ & $27.9^{\mathrm{a}}$ & $27.9^{\mathrm{a}}$ & 0.4 \\
Plasma protein, g/dL & $6.8^{\mathrm{a}}$ & $6.8^{\mathrm{a}}$ & $7.0^{\mathrm{a}}$ & 0.1 \\
Milk fat, \% & $3.5^{\mathrm{b}}$ & $3.6^{\mathrm{ab}}$ & $3.9^{\mathrm{a}}$ & 0.1 \\
Milk protein, \% & $3.2^{\mathrm{b}}$ & $3.3^{\mathrm{b}}$ & $3.4^{\mathrm{a}}$ & 0.1 \\
Milk lactose, \% & $4.9^{\mathrm{a}}$ & $4.8^{\mathrm{ab}}$ & $4.6^{\mathrm{b}}$ & 0.1 \\
Log SCC & $4.6^{\mathrm{c}}$ & $4.8^{\mathrm{b}}$ & $5.1^{\mathrm{a}}$ & 0.1 \\
Milk yield (p.m.), kg & $21.2^{\mathrm{a}}$ & $19.8^{\mathrm{a}}$ & $10.3^{\mathrm{b}}$ & 1.2 \\
Milk E $_{1}$ mass, ${ }^{2} \mathrm{ng}$ & $14.2^{\mathrm{c}}$ & $153.5^{\mathrm{b}}$ & $293.0^{\mathrm{a}}$ & 33.1 \\
Milk E $_{2}$ mass, ${ }^{2} \mathrm{ng}$ & $5.4^{\mathrm{c}}$ & $16.2^{\mathrm{b}}$ & $39.4^{\mathrm{a}}$ & 5.0 \\
\hline
\end{tabular}

${ }^{\mathrm{a}-\mathrm{c}}$ Means within rows with different superscripts differ $(P<0.05)$.

${ }^{1}$ Trimester: $1=50$ to $93 \mathrm{~d}$ pregnant ( $\mathrm{n}=18$ to 22 samples); $2=94$ to $186 \mathrm{~d}$ pregnant ( $\mathrm{n}=42$ to 47 samples); $3=187$ to $246 \mathrm{~d}$ pregnant ( $\mathrm{n}=26$ to 29 samples).

${ }^{2}$ Milk $\mathrm{E}_{1}$ and $\mathrm{E}_{2}$ mass $=\mathrm{E}_{1}$ or $\mathrm{E}_{2}$ concentration $(\mathrm{pg} / \mathrm{mL}) \times \mathrm{p} . \mathrm{m}$. milk yield $(\mathrm{mL})$. Milk volume $(\mathrm{mL})$ was calculated using the following conversion factors beginning with kilograms of milk: $1 \mathrm{~L}$ of milk/ $1.032 \mathrm{~kg}$ of milk, $1,000 \mathrm{~mL}$ of milk/1 L of milk.

$246 \mathrm{~d}$ of pregnancy for a total of 98 blood and 98 milk samples. The final blood and milk samples were collected from cows at a mean of $237 \pm 7( \pm \mathrm{SD})$ days of pregnancy. Due to the designation of trimesters and timing of sample collection, $22 \%(\mathrm{n}=22)$ of the samples were taken during trimester 1 and $48 \%(\mathrm{n}=47)$ were collected during trimester 2 , with the remaining $30 \%$ $(n=29)$ of samples being collected in trimester 3 . Cows had an average gestation length of $274 \pm 11 \mathrm{~d}$.

Body weight averaged $636 \pm 18 \mathrm{~kg}$ on the first sampling day and increased $(P<0.05)$ throughout pregnancy (Table 1). Hematocrit averaged $27.7 \pm 0.4 \%$ and was greater $(P<0.05)$ in trimesters 2 and 3 compared with trimester 1 (Table 1 ). Plasma protein averaged 6.8 $\pm 0.1 \%$ and did not differ based on trimester (Table 1 ).

Milk composition was normal for a well-managed Holstein herd. Log SCC and percentages of fat, protein, and lactose averaged $4.9 \pm 0.1$ cells $/ \mathrm{mL}, 3.6 \pm 0.2 \%, 3.3$ $\pm 0.1 \%$, and $4.7 \pm 0.1 \%$, respectively. Milk yield for the p.m. milking averaged $17.7 \pm 1.2 \mathrm{~kg}$ overall and was lower $(P<0.001)$ in trimester 3 compared with trimesters 1 and 2 (Table 1 ).

Recoveries of tritiated $\mathrm{E}_{1}$ and $\mathrm{E}_{2}$ standards through the extraction and isolation procedures averaged $98 \%$ for both plasma and milk $\mathrm{E}_{1}$ and $75 \%$ for both plasma and milk $\mathrm{E}_{2}$. Overall, plasma $\mathrm{E}_{1}$ concentration averaged $20.2 \mathrm{pg} / \mathrm{mL}$ (range $=0.6$ to $77.6 \mathrm{pg} / \mathrm{mL}$ ), and milk $\mathrm{E}_{1}$ concentration averaged $11.0 \mathrm{pg} / \mathrm{mL}$ (range $=0.3$ to 94.2 $\mathrm{pg} / \mathrm{mL}$ ). Plasma $\mathrm{E}_{2}$ concentration averaged $1.1 \mathrm{pg} / \mathrm{mL}$ (range $=$ nondetectable to $7.4 \mathrm{pg} / \mathrm{mL})$, and milk $\mathrm{E}_{2}$ concentration averaged $1.9 \mathrm{pg} / \mathrm{mL}$ (range $=$ nondetectable to $22.3 \mathrm{pg} / \mathrm{mL}$ ). Plasma and milk $\mathrm{E}_{1}$ and $\mathrm{E}_{2}$ concentra-

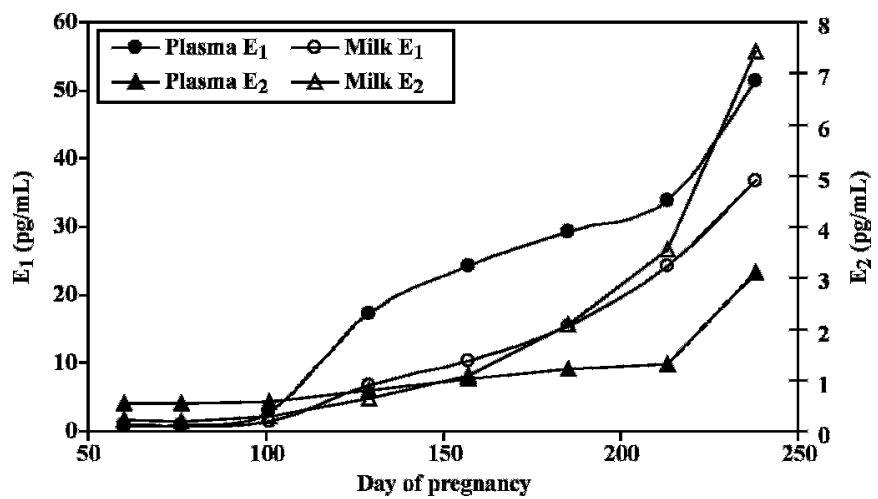

Figure 1. Mean concentrations of estrone $\left(\mathrm{E}_{1}\right)$ and $17 \beta$-estradiol $\left(\mathrm{E}_{2}\right)$ in plasma and milk throughout pregnancy in 13 lactating Holstein dairy cows. Blood and milk samples were initially collected at an average of $11 \mathrm{~d}$ after confirmation of pregnancy and every $28 \mathrm{~d}$ thereafter throughout pregnancy. The average standard deviation for days pregnant on the x-axis was $4.5 \mathrm{~d}$. Plasma $\mathrm{E}_{1}$ standard error of the means $=2.8 \mathrm{pg} / \mathrm{mL} ;$ milk $\mathrm{E}_{1}$ standard error of the means $=2.4$ $\mathrm{pg} / \mathrm{mL}$; plasma $\mathrm{E}_{2}$ standard error of the means $=0.2 \mathrm{pg} / \mathrm{mL} ;$ milk $\mathrm{E}_{2}$ standard error of the means $=0.6 \mathrm{pg} / \mathrm{mL}$.

tions each increased during pregnancy (Figure 1). Parity had no effect on the concentrations of $E_{1}$ and $E_{2}$ in plasma and milk.

Plasma $\mathrm{E}_{1}$ concentrations increased $(P<0.001)$ from $0.8 \mathrm{pg} / \mathrm{mL}$ in trimester 1 to $41.8 \mathrm{pg} / \mathrm{mL}$ in trimester 3 (Figure 2). The $\mathrm{E}_{1}$ concentrations in milk increased ( $P$ $<0.05$ ) from $<1 \mathrm{pg} / \mathrm{mL}$ in trimester 1 to $27.1 \mathrm{pg} / \mathrm{mL}$ by trimester 3 (Figure 2). The calculated $\mathrm{E}_{1}$ milk-toplasma ratio averaged $0.8,0.5$, and 0.6 in trimesters 1 , 2 , and 3, respectively, with only small differences among trimesters. The mass of $\mathrm{E}_{1}$ accumulated in milk over a 12 -h period (as calculated by multiplying milk $\mathrm{E}_{1}$ concentrations by p.m. milk volume, $\mathrm{mL}$ ) increased $(P<0.01$; Table 1$)$ throughout pregnancy.

Mean concentrations of $\mathrm{E}_{2}$ in plasma increased from $0.5 \mathrm{pg} / \mathrm{mL}$ in trimester 1 to $2.0 \mathrm{pg} / \mathrm{mL}$ in trimester 3 (Figure 2). Plasma $\mathrm{E}_{2}$ concentrations in trimester 3 were greater compared with trimesters 1 and $2(P<$ $0.001)$. The $\mathrm{E}_{2}$ concentrations in milk averaged $0.3 \mathrm{pg} /$ $\mathrm{mL}$ in trimester 1 and $5.0 \mathrm{pg} / \mathrm{mL}$ in trimester 3 . Milk $\mathrm{E}_{2}$ concentrations in trimester 3 were greater compared with trimesters 1 and $2(P<0.001$; Figure 2$)$. The $\mathrm{E}_{2}$ milk-to-plasma ratios averaged $0.4,0.8$, and 2.2 in trimesters 1,2 , and 3, respectively, and increased with advancing pregnancy $(P<0.05)$. The mass of $\mathrm{E}_{2}$ accumulated in milk over a 12 -h period (as calculated by multiplying milk $\mathrm{E}_{2}$ concentrations by p.m. milk volume, $\mathrm{mL}$ ) also increased throughout pregnancy $(P<0.05$; Table 1$)$.

Milk $\mathrm{E}_{1}$ was most highly correlated with plasma $\mathrm{E}_{1}$ $(\mathrm{r}=0.77)$, days pregnant $(\mathrm{r}=0.67)$, plasma $\mathrm{E}_{2}(\mathrm{r}=0.55)$, percentage milk fat $(\mathrm{r}=0.50)$, and milk yield $(\mathrm{r}=-0.43$; each $P<0.01$; Table 2). Milk $\mathrm{E}_{2}$ was most highly corre- 

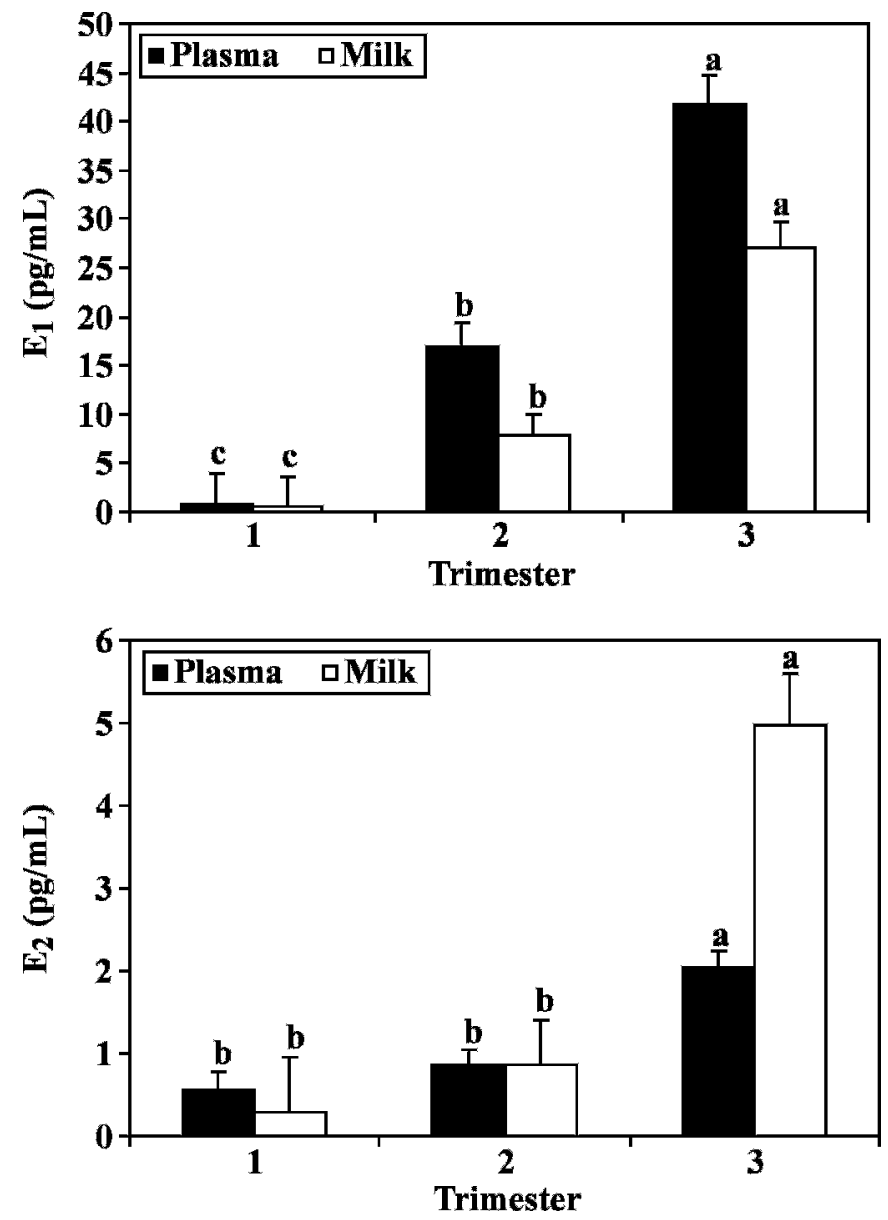

Figure 2. Mean estrone $\left(\mathrm{E}_{1}\right.$; top panel) and $17 \beta$-estradiol $\left(\mathrm{E}_{2}\right.$; lower panel) concentrations in plasma and milk during pregnancy. Bars represent plasma and milk $\mathrm{E}_{1}$ or $\mathrm{E}_{2}$ concentrations $(\mathrm{pg} / \mathrm{mL})$ during trimesters 1 (50 to $93 \mathrm{~d}$ pregnant, $\mathrm{n}=22$ samples), 2 (94 to $186 \mathrm{~d}$ pregnant, $\mathrm{n}=47$ samples), and 3 ( 187 to $246 \mathrm{~d}$ pregnant, $\mathrm{n}=29$ samples). ${ }^{a-c}$ Bars within sample type (plasma or milk) with different letters differ $(P<0.001)$.

lated with plasma $\mathrm{E}_{2}(\mathrm{r}=0.93)$, plasma $\mathrm{E}_{1}(\mathrm{r}=0.71)$, percentage of milk protein $(\mathrm{r}=0.63)$, days pregnant $(\mathrm{r}=$ 0.57 ), and milk yield ( $\mathrm{r}=-0.57$; each $P<0.01$; Table 2 ). The $\mathrm{E}_{2}$ in milk was also positively correlated with $\log$ SCC in milk $(r=0.40$; Table 2$)$.

\section{DISCUSSION}

Cows in this study gained, on average, $53.6 \mathrm{~kg}$ between trimesters 1 and 2 and $53.0 \mathrm{~kg}$ between trimesters 2 and 3 . The substantial weight gain during pregnancy is consistent with the developing uterine-conceptus mass as well as a significant increase in body condition. Hematocrit concentrations averaged 27.7\%, which was similar to observations of Eley et al. (1981), Lee et al. (1978), and Smith (2002). Plasma proteins in the present study averaged $6.8 \mathrm{~g} / \mathrm{dL}$, which is similar to the $6.9 \mathrm{~g} / \mathrm{dL}$ observed in lactating cows (Eley et al., 1981).

Parity had no effect on the concentrations of $\mathrm{E}_{1}$ and $\mathrm{E}_{2}$ in milk, consistent with results from a previous experiment with a larger number of cows (Pape-Zambito et al., 2007). Plasma and milk $\mathrm{E}_{1}$ and $\mathrm{E}_{2}$ concentrations increased throughout gestation, with plasma $\mathrm{E}_{1}$ increasing earlier than plasma $\mathrm{E}_{2}$ (Figure 1 ). The greatest concentrations of $\mathrm{E}_{1}$ and $\mathrm{E}_{2}$ were found in the last plasma and milk samples (average $=238 \mathrm{~d}$ pregnant), when most dairy cows in the United States are not lactating. Plasma and milk $\mathrm{E}_{1}$ increased throughout pregnancy, whereas $\mathrm{E}_{2}$ significantly increased in trimester 3 of pregnancy in lactating pregnant Holstein dairy cows (Figure 2). Others have reported that plasma $\mathrm{E}_{1}$ (Robinson et al., 1970) and $\mathrm{E}_{2}$ (Monk et al., 1975; Robertson and King, 1979; Patel et al., 1999) increased during pregnancy in the cow. Monk et al. (1975) did not observe an increase in milk $\mathrm{E}_{1}$ and $\mathrm{E}_{2}$ during pregnancy, but they did not sample as late in pregnancy as in the current study. Pape-Zambito et al. (2007) reported that $\mathrm{E}_{2}$ concentrations in raw whole milk were greater in cows that were 141 to $210 \mathrm{~d}$ pregnant than in cows < $141 \mathrm{~d}$ pregnant ( $3.0 \mathrm{vs} .0 .9 \mathrm{pg} / \mathrm{mL}$, respectively). Malekinejad et al. (2006) reported increased concentrations of $\mathrm{E}_{1}$ and $\mathrm{E}_{2}$ in raw milk throughout pregnancy; however, only 5 cows were sampled from each trimester. In addition, milk samples from each trimester were pooled before analyses, and statistical differences among trimesters were not presented. The repeated measures analysis in the present experiment has merit in that animal variation was not confounded with pregnancy stage. Heap and Hamond (1979) and Malekinejad et al. (2006) reported greater $\mathrm{E}_{1}$-sulfate concentrations in milk from pregnant cows, particularly during the latter half of pregnancy. The present experiment, to our knowledge, is the first to show a significant increase in $\mathrm{E}_{1}$ and $\mathrm{E}_{2}$ in milk during pregnancy using within-cow comparisons. Future studies will examine the concentrations of conjugated estrogens in milk from both nonpregnant and pregnant cows.

Plasma $\mathrm{E}_{1}$ was correlated with plasma $\mathrm{E}_{2}(\mathrm{r}=0.74$, Table 2). Eley et al. (1981) also noted a positive correlation $(\mathrm{r}=0.54)$ between plasma $\mathrm{E}_{1}$ and $\mathrm{E}_{2}$ in late pregnant dry cows. Plasma $\mathrm{E}_{1}$ was correlated with milk $\mathrm{E}_{1}$ in the present study $(\mathrm{r}=0.77$, Table 2$)$, and plasma $\mathrm{E}_{2}$ was significantly correlated with milk $\mathrm{E}_{2}(\mathrm{r}=0.93$, Table 2). The correlations between plasma and milk estrogens suggest that plasma $\mathrm{E}_{1}$ and $\mathrm{E}_{2}$ may passively diffuse from the plasma through mammary epithelial cells to the alveolar lumen where milk is accumulated. Batra et al. (1980) reported a high correlation between plasma and milk $\mathrm{E}_{2}$ during pregnancy in buffaloes. 
Table 2. Correlation coefficients among plasma and milk estrone $\left(\mathrm{E}_{1}\right)$ and $17 \beta$-estradiol $\left(\mathrm{E}_{2}\right)$ concentrations and milk components ${ }^{1}$

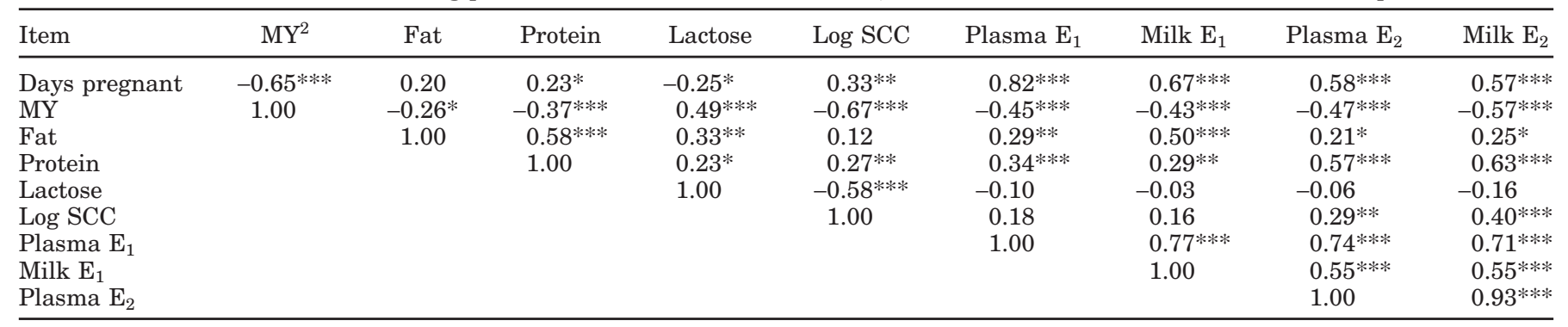

${ }^{1}$ Numbers in the table represent correlation coefficients for the comparisons of interest with $\mathrm{n}=94$ to 98 samples for each cell.

${ }^{2} \mathrm{MY}=$ milk yield.

$* P<0.05 ; * * P<0.01 ; * * * P<0.001$.

The milk:plasma ratio of $\mathrm{E}_{1}$ remained below 1 throughout pregnancy (Figure 2). Perhaps the presence of binding proteins in plasma reduces diffusion of $\mathrm{E}_{1}$ into the mammary glands. In contrast, the milk:plasma ratio of $\mathrm{E}_{2}$ increased throughout pregnancy in the present experiment (Figure 2). This suggests that, as gestation progresses, either some specific blood-to-milk transport mechanism evolves or that cells within the mammary gland develop the ability to produce $\mathrm{E}_{2}$. Keller et al. (1977) stated that the mammary glands might selectively accumulate $\mathrm{E}_{2}$ or convert other estrogens to $\mathrm{E}_{2}$, given that milk $\mathrm{E}_{2}$ concentrations were greater than those in plasma. Maule-Walker and Peaker (1978), Maule-Walker et al. (1983), and Peaker and Taylor (1990) reported greater quantities of $\mathrm{E}_{2}$ in mammary venous blood compared with arterial blood during late pregnancy and suggested the mammary glands produced $\mathrm{E}_{2}$. Peaker and Taylor (1990) and Janowski et al. (2002) reported that mammary tissue from late pregnant animals converted ${ }^{3} \mathrm{H}$-androstenedione to ${ }^{3} \mathrm{H}-\mathrm{E}_{2}$, a reaction that requires the aromatase (CYP19) enzyme. Belvedere et al. (1996) detected aromatase transcripts in mammary tissue from late lactation cows but not in nonlactating-nonpregnant cows. Other than aromatase, little has been reported on other enzymes that may be involved in mammary cell steroid biosynthesis.

Milk $\mathrm{E}_{1}$ and $\mathrm{E}_{2}$ in the present study were positively correlated with milk fat and protein percentages. The more lipophilic $\mathrm{E}_{1}$ was more highly correlated with milk fat percentage than was milk $\mathrm{E}_{2}$ with milk fat percentage ( $\mathrm{r}=0.50$ vs. 0.25 ). Wolford and Argoudelis (1979) reported that $80 \%$ of milk $\mathrm{E}_{1}$ but only $65 \%$ of milk $\mathrm{E}_{2}$ was associated with the fat in milk after they incubated radiolabeled estrogens with milk and then separated and counted both fat and skim fractions. Our results are consistent with the conclusions of Wolford and Argoudelis (1979) but reflect partitioning of $\mathrm{E}_{1}$ and $\mathrm{E}_{2}$ during milk biosynthesis. Pape-Zambito et al. (2007) reported a correlation of 0.20 between percentage of milk fat and $\mathrm{E}_{2}$ concentration in milk from over 200 cows when adjusted for trimester of pregnancy. This is similar to the correlation in the present study (0.25).

Milk $\mathrm{E}_{1}$ and $\mathrm{E}_{2}$ concentrations in the present study were also correlated with percentage of milk protein $(r=0.29$ and 0.63 , respectively). Wolford and Argoudelis (1979) reported that 84 to $85 \%$ of $E_{1}$ and $E_{2}$ found in skim milk were bound to proteins. Albumin is a minor whey protein in normal milk, but in plasma, albumin can nonspecifically transport both $\mathrm{E}_{1}$ and $\mathrm{E}_{2}$ throughout the body (Pardridge, 1986). Perhaps because $\mathrm{E}_{1}$ is more hydrophobic than $\mathrm{E}_{2}$, it associates to a greater degree with fat-soluble molecules, whereas the relatively more hydrophilic $\mathrm{E}_{2}$ tends to associate with albumin or some other protein(s) during milk synthesis.

Milk $\mathrm{E}_{2}$ concentrations were correlated with log SCC $(\mathrm{r}=0.40$, Table 2$)$. It is possible that plasma proteins that transport $\mathrm{E}_{2}$ may enter the alveolar lumen as tight junctions open during the passage of somatic cells or that somatic cells in milk have the ability to convert $\mathrm{E}_{1}$ to $\mathrm{E}_{2}$, leading to an increase in milk $\mathrm{E}_{2}$ concentrations. The enzyme required for this conversion is $17 \beta$ hydroxysteroid dehydrogenase. It would be interesting to determine if milk somatic cells possess $17 \beta$-hydroxysteroid dehydrogenase activity. The correlations between milk $\mathrm{E}_{1}$ and $\mathrm{E}_{2}$ and milk components provide an insight into the complex manner by which $\mathrm{E}_{1}$ and $\mathrm{E}_{2}$ accumulate in the alveolar lumen. Results from the present study suggest that $\mathrm{E}_{1}$ and $\mathrm{E}_{2}$ accumulate in milk by somewhat different mechanisms.

The absolute concentrations of both plasma and milk $\mathrm{E}_{1}$ and $\mathrm{E}_{2}$ in our study are low relative to some reports in the literature (Monk et al., 1975; Erb et al., 1977; Patel et al., 1999) but are similar to others (Glencross et al., 1973; Glencross and Abeywardene, 1983; Abeyawardene et al., 1984). The trend for increased plasma $\mathrm{E}_{1}$ and $\mathrm{E}_{2}$ concentrations during pregnancy is consistent across studies. Zdunczyk et al. (2001) did not detect $\mathrm{E}_{2}$ 
in plasma or milk during pregnancy, and Hoffmann et al. (1997) were not able to detect $\mathrm{E}_{2}$ in plasma until $10 \mathrm{~d}$ before parturition. These examples illustrate the sensitivity required to measure $\mathrm{E}_{2}$ in bovine plasma and milk. The range of $\mathrm{E}_{2}$ concentrations in milk in the current study (nondetectable to $22.3 \mathrm{pg} / \mathrm{mL}$ ) agree with concentrations reported previously by our lab (PapeZambito et al., 2007). Pape-Zambito et al. (2007) and Monk et al. (1975) discussed factors including sample processing, the $\mathrm{E}_{2}$ standard, and $\mathrm{E}_{2}$ antibody that may explain differences in absolute concentrations reported in the literature. A specific issue may be related to the cross-reactivity of the $\mathrm{E}_{2}$ antibody with other estrogens. The antibody used in the present study cross-reacted $0.68 \%$ with $17 \alpha$-estradiol, whereas previous reports have noted a 17 to $32 \%$ cross-reactivity of the $\mathrm{E}_{2}$ antibody with $17 \alpha$-estradiol (Monk et al., 1975; Eley et al., 1981). Janowski et al. (2002) reported that $17 \alpha$-estradiol concentrations in plasma were greater than $\mathrm{E}_{1}$ or $\mathrm{E}_{2}$ concentrations in late pregnancy. Thus, antibodies used to detect $\mathrm{E}_{2}$ that significantly cross-react with $17 \alpha$ estradiol would yield artificially high estimates of $\mathrm{E}_{2}$.

More recent technologies, such as GC-MS and liquid chromatography tandem mass spectrometry (LC/MSMS), have been utilized to quantify estrogens in milk (Hartmann et al., 1998; Malekinejad et al., 2006). These methods are advantageous in that they do not rely on antibody-based detection. It is also possible to analyze multiple estrogens at a time $\left(\mathrm{E}_{1}+\mathrm{E}_{2}+\right.$ estriol); however, it can be difficult to optimize a single method for all estrogens of interest (Giese, 2003). Recently, Farre et al. (2007) quantified $\mathrm{E}_{2}$ from municipal waste, river, and ground waters using ELISA (an antibody-based detection system), HPLC mass spectrometry, and ultraperformance liquid chromatography quadrupole-time of flight mass spectrometry. Ultra-performance liquid chromatography quadrupole-time of flight mass spectrometry was the most sensitive method followed by ELISA then LC/MS-MS. The authors concluded that results from all techniques were in general agreement (Farre et al., 2007). Many investigators do not have access to the sensitive equipment required for GC-MS, LC/MS-MS, or ultra-performance liquid chromatography quadrupole-time of flight mass spectrometry analysis of estrogens in bovine samples where concentrations are generally below $100 \mathrm{pg} / \mathrm{mL}$, or the cost for sample analysis using these techniques is too expensive. Therefore, antibody-based technologies such as RIA and ELISA are widely used due to the specificity of modern antibodies, sensitivity of the method, as well as the cost or sample.

One other notable difference between our study and others may be related to milk yield (MY). Cows in the Pennsylvania State dairy herd had an average 305-d mature equivalent of $11,465 \mathrm{~kg}$, which is likely greater than MY of dairy cows in European countries and US dairy cows in the 1970s and 1980s. Milk yield was negatively correlated with both milk $\mathrm{E}_{1}$ and milk $\mathrm{E}_{2}$ in the present study (Table 2), as well as in Pape-Zambito et al. (2007). Eley et al. (1981) compared $E_{1}$ and $E_{2}$ concentrations in plasma from cows that had been selected for increased MY to those in cows not selected for increased MY (control). Interestingly, cows that were selected for increased MY tended $(P<0.10)$ to have lower concentrations of plasma $\mathrm{E}_{1}$ compared with control cows. Sangsritavong et al. (2002) reported that increased DM intake (observed in high-producing dairy cows) can increase liver blood flow and increase metabolic clearance rate of both progesterone and $\mathrm{E}_{2}$. Increased metabolic clearance rates of progesterone and $\mathrm{E}_{2}$ can reduce circulating concentrations of these hormones (Lopez et al., 2004). Therefore, the low $\mathrm{E}_{1}$ and $\mathrm{E}_{2}$ concentrations in milk in the present study relative to others (Monk et al., 1975; Wolford and Argoudelis, 1979; Malekinejad et al., 2006), may be explained in part by greater MY of cows in the present study.

Ganmaa and Sato (2005) speculated that today a greater proportion of high-producing pregnant cows are being milked compared with $100 \mathrm{yr}$ ago, and this contributes to greater quantities of estrogens in the consumable milk supply. Wiltbank et al. (2006) suggested that high-producing dairy cows have increased metabolic clearance rates of $\mathrm{E}_{2}$ with resultant decreased circulating concentrations of $\mathrm{E}_{2}$, which, in turn, may affect fertility in modern high-producing cattle. The decrease in circulating concentrations of $\mathrm{E}_{2}$ over time likely would result in decreased concentrations of $\mathrm{E}_{2}$ in milk, because milk concentrations are significantly correlated with plasma concentrations (Table 2). Thus, in contrast to Ganmaa and Sato (2005), it is likely that milk produced by modern high-producing dairy cows actually would have less $\mathrm{E}_{2}$ compared with milk from cows from 100 yr ago.

Although we did observe a significant increase in milk $\mathrm{E}_{1}$ and $\mathrm{E}_{2}$ concentrations during pregnancy, it is important to point out that the final trimester 3 samples were collected at a time when cows are usually nonlactating (>220 d pregnant). Milk from cows $>220 \mathrm{~d}$ pregnant would generally not be consumed by people or would represent an insignificant fraction of the milk supply. Much of the milk entering the bulk tank on a dairy farm is from nonpregnant cows with a small percentage $(<20 \%)$ of cows in a herd producing milk during the last trimester of pregnancy. Based upon the data in Figure 1, data from Pape-Zambito et al. (2007), and the knowledge that early lactation cows have high milk yields, it is likely that the majority of cows producing milk for consumption would have $<10 \mathrm{pg}$ of $\mathrm{E}_{1} / \mathrm{mL}$ 
of milk and $<2 \mathrm{pg} \mathrm{E}_{2} / \mathrm{mL}$ milk. This estimate is based upon the assumption that the average Holstein cow is 201 DIM (Dairy Records Management Systems, Raleigh, NC), that average days open is 122 (Hare et al., 2006), that farmers generally dry off cows at $60 \mathrm{~d}$ before the next expected calving, and that pasteurization and homogenization do not affect concentrations of $E_{1}$ or $\mathrm{E}_{2}$ in milk (Pape-Zambito et al., 2006). Using mean concentrations of $\mathrm{E}_{1}$ and $\mathrm{E}_{2}$ for pregnant cows in the present study, the combined amount of $\mathrm{E}_{1}$ and $\mathrm{E}_{2}$ consumed in 3 servings ( $711 \mathrm{~mL}$ or $24 \mathrm{fl}$. oz.) of whole milk would be $9.6 \mathrm{ng}$. This exposure value does not take into account the potential for lower $\mathrm{E}_{1}$ and $\mathrm{E}_{2}$ concentrations in bulk tank milk (because bulk tank milk would contain a considerable amount of milk from nonpregnant cows) and lower fat milk (Malekinejad et al., 2006; our own unpublished results), as well as either fecal excretion or first-pass metabolism by the gastrointestinal mucosa and liver of orally ingested estrogens (Ruoff and Dziuk, 1994; O'Connell, 1995). It has been reported that prepubertal girls produce 54,000 ng of $\mathrm{E}_{1}+\mathrm{E}_{2} / \mathrm{d}$ and that prepubertal boys produce $100,000 \mathrm{ng}$ of $\mathrm{E}_{1}+$ $\mathrm{E}_{2} / \mathrm{d}$ (as reported in Hartmann et al., 1998). Thus, a conservative estimate of the mass of $\mathrm{E}_{1}+\mathrm{E}_{2}$ in 3 servings of milk represents $0.02 \%$ of what prepubertal girls produce daily. The low concentrations of $E_{1}$ and $E_{2}$ in milk, therefore, are unlikely to pose a health risk to humans. However, additional research on concentrations of estrogen conjugates in milk, as well as bioavailability and absorption rates of orally ingested estrogens in milk, is required to ascertain true biological risk to humans.

\section{CONCLUSIONS}

Plasma and milk $\mathrm{E}_{1}$ and $\mathrm{E}_{2}$ were greater in trimester 3 of pregnancy compared with trimesters 1 and 2 in lactating Holstein dairy cows. The $\mathrm{E}_{1}$ concentrations were 0.91 and $0.69 \mathrm{pg} / \mathrm{mL}$ at $60 \mathrm{~d}$ of pregnancy in plasma and milk, respectively, and concentrations increased to 51.3 and $36.7 \mathrm{pg} / \mathrm{mL}$ by d 238 of pregnancy. The $\mathrm{E}_{2}$ concentrations averaged 0.53 and $0.22 \mathrm{pg} / \mathrm{mL}$ at $60 \mathrm{~d}$ of pregnancy in plasma and milk, respectively, and increased to 3.1 and $7.4 \mathrm{pg} / \mathrm{mL}$ by d 238 of pregnancy. The $\mathrm{E}_{2}$ concentrations in plasma were greater than those in milk during trimester 1 (milk:plasma ratio $=0.4$ ), but in trimester 3 of pregnancy, milk concentrations exceeded those in plasma (milk:plasma ratio $=2.2$ ). This change may indicate that cells within the mammary gland acquire the capacity to produce $\mathrm{E}_{2}$ from a precursor steroid. Milk $\mathrm{E}_{1}$ concentrations were positively correlated with plasma $\mathrm{E}_{1}$ concentrations and percentage of milk fat and were negatively correlated with milk yield. The $\mathrm{E}_{2}$ concentrations in milk were positively correlated with $\mathrm{E}_{2}$ concentrations in plasma and percentage of milk protein and negatively correlated with milk yield. Results suggest that $\mathrm{E}_{1}$ and $\mathrm{E}_{2}$ accumulate in milk by somewhat different mechanisms. The concentrations of $\mathrm{E}_{1}$ and $\mathrm{E}_{2}$ consumed from milk are extremely low relative to endogenous 24 -h production rates of $\mathrm{E}_{1}$ and $\mathrm{E}_{2}$ in humans.

\section{ACKNOWLEDGMENTS}

This work was supported by funds from USDA Special Grant no. 2003-34163-13404 to Ronald Kensinger. The authors also thank the staff at the Pennsylvania Dairy Research and Education Center, plus Penn State students Michael Harper and Shannon VanDyke for help with sample preparation and Michael O'Connor (Penn State) for providing national Holstein dairy herd statistics.

\section{REFERENCES}

Abeyawardene, S. A., D. J. Hathorn, and R. G. Glencross. 1984. Concentrations of oestradiol- $17 \beta$ and progesterone in bovine plasma and defatted milk during the post-partum anovulatory period, during oestrous cycles and following ovariectomy. Br. Vet. J. 140:458-467.

Batra, S. K., R. C. Arora, N. K. Bachlaus, G. S. Pahwa, and R. S. Pandey. 1980. Quantitative relationships between oestradiol-17 $\beta$ in the milk and blood of lactating buffaloes. J. Endocrinol. 84:205-209

Belvedere, P., G. Gabai, L. Dalla Valle, P. Accorsi, M. Trivoletti, L. Colombo, and G. Bono. 1996. Occurrence of steroidogenic enzymes in the bovine mammary gland at different functional stages. J. Steroid Biochem. Mol. Biol. 59:339-347.

Berkey, C. S., H. R. Rockett, W. C. Willett, and G. A. Colditz. 2005 Milk, dairy fat, dietary calcium, and weight gain: A longitudinal study of adolescents. Arch. Pediatr. Adolesc. Med. 159:543-550.

Cho, E., D. Spiegelman, D. J. Hunter, W. Y. Chen, M. J. Stampfer, G. A. Colditz, and W. C. Willett. 2003. Premenopausal fat intake and risk of breast cancer. J. Natl. Cancer Inst. 95:1079-1085.

Eley, D. S., W. W. Thatcher, H. H. Head, R. J. Collier, and C. J. Wilcox. 1981. Periparturient endocrine changes of conceptus and maternal units in Jersey cows bred for milk yield. J. Dairy Sci. 64:296-311.

Erb, R. E., B. P. Chew, and H. F. Keller. 1977. Relative concentrations of estrogen and progesterone in milk and blood, and excretion of estrogen in urine. J. Anim. Sci. 46:617-626.

Farre, M., M. Kuster, R. Brix, F. Rubio, M. J. Lopez de Alda, and D. Barcelo. 2007. Comparative study of an estradiol enzyme-linked immunosorbent assay kit, liquid chromatography-tandem mass spectrometry, and ultra performance liquid chromatographyquadrupole time of flight mass spectrometry for part-per-trillion analysis of estrogens in water samples. J. Chromatogr. A 1160:166-175.

Ganmaa, D., L. Q. Qin, P. Y. Wang, H. Tezuka, S. Teramoto, and A. Sato. 2004. A two-generation reproduction study to assess the effects of cows' milk on reproductive development in male and female rats. Fertil. Steril. 82:1106-1114.

Ganmaa, D., and A. Sato. 2005. The possible role of female sex hormones in milk from pregnant cows in the development of breast, ovarian and corpus uteri cancers. Med. Hypotheses 65:10281037.

Ganmaa, D., P. Y. Wang, L. Q. Qin, K. Hoshi, and A. Sato. 2001. Is milk responsible for male reproductive disorders? Med. Hypotheses 57:510-514. 
Giese, R. W. 2003. Measurement of endogenous estrogens: Analytical challenges and recent advances. J. Chromatogr. A 1000:401-412.

Glencross, R. G., and S. A. Abeywardene. 1983. Concentrations of oestradiol 17- $\beta$ and progesterone in plasma and defatted milk of cattle during the oestrous cycle. Br. Vet. J. 139:49-51.

Glencross, R. G., I. B. Munro, B. E. Senior, and G. S. Pope. 1973. Concentrations of oestradiol- $17 \beta$, oestrone and progesterone in jugular venous plasma of cows during the oestrous cycle and in early pregnancy. Acta Endocrinol. (Cph.) 73:374-384.

Hare, E., D. Norman, and J. R. Wright. 2006. Trends in calving ages and calving intervals for dairy cattle breeds in the United States. J. Dairy Sci. 89:365-370.

Hartmann, S., M. Lacorn, and H. Steinhart. 1998. Natural occurrence of steroid hormones in food. Food Chem. 62:7-20.

Heap, R. B., and M. Hamond. 1979. Oestrone sulphate in milk as an indicator of a viable conceptus in cows. Br. Vet. J. 135:355-363.

Hoffmann, B., T. Goes de Pinho, and G. Schuler. 1997. Determination of free and conjugated oestrogens in peripheral blood plasma, feces and urine of cattle throughout pregnancy. Exp. Clin. Endocrinol. Diabetes 105:296-303.

Janowski, T., S. Zdunczyk, J. Malecki-Tepicht, W. Baranski, and A. Ras. 2002. Mammary secretion of oestrogens in the cow. Domest. Anim. Endocrinol. 23:125-137.

Keller, H. F., B. P. Chew, R. E. Erb, and P. V. Malven. 1977. Mammary transfer of hormones and constituents into secretions when cows were milked or secretions were sampled prepartum. J. Dairy Sci. 60:546-556.

Kensinger, R. S., R. J. Collier, F. W. Bazer, and R. R. Kraeling. 1986. Effect of number of conceptuses on maternal hormone concentrations in the pig. J. Anim. Sci. 62:1666-1674.

Lee, A. J., A. R. Twardock, R. H. Bubar, J. E. Hall, and C. L. Davis. 1978. Blood metabolic profiles: Their use and relation to nutritional status of dairy cows. J. Dairy Sci. 61:1652-1670.

Li, X. M., D. Ganmaa, and A. Sato. 2003. The experience of Japan as a clue to the etiology of breast and ovarian cancers: Relationship between death from both malignancies and dietary practices. Med. Hypotheses 60:268-275.

Lopez, H., L. D. Satter, and M. C. Wiltbank. 2004. Relationship between level of milk production and estrous behavior of lactating dairy cows. Anim. Reprod. Sci. 81:209-223.

Malekinejad, H., P. Scherpenisse, and A. A. Bergwerff. 2006. Naturally occurring estrogens in processed milk and in raw milk (from gestated cows). J. Agric. Food Chem. 54:9785-9791.

Maule-Walker, F. M., A. J. Davis, and I. R. Fleet. 1983. Endocrine activity of the mammary gland: Oestrogen and prostaglandin secretion by the cow and sheep mammary glands during lactogenesis. Br. Vet. J. 139:171-177.

Maule-Walker, F. M., and M. Peaker. 1978. Production of oestradiol $17-\beta$ by the goat mammary gland during late pregnancy in relation to lactogenesis. J. Physiol. 284:71P.

Mikhail, G., C. H. Wu, M. Ferin, and R. L. Vande Wiele. 1970. Radioimmunoassay of plasma estrone and estradiol. Steroids 15:333-352.

Monk, E. L., R. E. Erb, and T. A. Mollett. 1975. Relationships between immunoreactive estrone and estradiol in milk, blood, and urine of dairy cows. J. Dairy Sci. 58:34-40.
O'Connell, M. B. 1995. Pharmacokinetic and pharmacologic variation between different estrogen products. J. Clin. Pharmacol. 35:1048-1059

Pape-Zambito, D. A., A. L. Magliaro, and R. S. Kensinger. 2007. Concentrations of $17 \beta$-estradiol in Holstein whole milk. J. Dairy Sci. 90:3308-3313.

Pape-Zambito, D. A., R. F. Roberts, N. M. Kauffman, and R. S. Kensinger. 2006. $17 \beta$-estradiol concentrations in raw and pasteurized/homogenized whole milk. J. Dairy Sci. 89(Suppl. 1):112. (Abstr.)

Pardridge, W. M. 1986. Serum bioavailability of sex steroid hormones. Clin. Endocrinol. Metab. 15:259-278.

Patel, O. V., N. Takenouchi, T. Takahashi, M. Hirako, N. Sasaki, and I. Domeki. 1999. Plasma oestrone and oestradiol concentrations throughout gestation in cattle: Relationship to stage of gestation and fetal number. Res. Vet. Sci. 66:129-133.

Peaker, M., and E. Taylor. 1990. Oestrogen production by the goat mammary gland: Transient aromatase activity during late pregnancy. J. Endocrinol. 125:R1-R3.

Qin, L. Q., J. Y. Xu, P. Y. Wang, D. Ganmaa, J. Li, J. Wang, T. Kaneko, K. Hoshi, T. Shirai, and A. Sato. 2004. Low-fat milk promotes the development of 7,12-dimethylbenz(A)anthracene (DMBA)-induced mammary tumors in rats. Int. J. Cancer 110:491-496.

Remesar, X., V. Tang, E. Ferrer, C. Torregrosa, J. Virgili, R. M. Masanes, J. A. Fernandez-Lopez, and M. Alemany. 1999. Estrone in food: A factor influencing the development of obesity? Eur. J. Nutr. 38:247-253.

Robertson, H. A., and G. J. King. 1979. Conjugated and unconjugated oestrogens in fetal and maternal fluids of the cow throughout pregnancy. J. Reprod. Fertil. 55:463-470.

Robinson, R., R. D. Baker, P. A. Anastassiadis, and R. H. Common. 1970. Estrone concentrations in the peripheral blood of pregnant cows. J. Dairy Sci. 53:1592-1596.

Ruoff, W. L., and P. J. Dziuk. 1994. Absorption and metabolism of estrogens from the stomach and duodenum of pigs. Domest. Anim. Endocrinol. 11:197-208.

Sangsritavong, S., D. K. Combs, R. Sartori, L. E. Armentano, and M. C. Wiltbank. 2002. High feed intake increases liver blood flow and metabolism of progesterone and estradiol- $17 \beta$ in dairy cattle. J. Dairy Sci. 85:2831-2842.

Sharpe, R. M., and N. E. Skakkebaek. 1993. Are oestrogens involved in falling sperm counts and disorders of the male reproductive tract? Lancet 341:1392-1395.

Smith, B. P. 2002. Large animal internal medicine. 3rd ed. Mosby, St. Louis, MO.

Wiltbank, M., H. Lopez, R. Sartori, S. Sangsritavong, and A. Gumen. 2006. Changes in reproductive physiology of lactating dairy cows due to elevated steroid metabolism. Theriogenology 65:17-29.

Wolford, S. T., and C. J. Argoudelis. 1979. Measurement of estrogens in cow's milk, human milk, and dairy products. J. Dairy Sci. 62:1458-1463.

Zdunczyk, S., J. Malecki-Tepicht, and T. Janowski. 2001. Levels of estrone, estradiol-17 $\beta$ and their conjugates in blood and milk of pregnant cows during lactation. Pol. J. Vet. Sci. 4:11-14. 